\title{
KEBIJAKAN KRIMINAL TERHADAP, GAY, BISEKSUAL DAN TRANSGENDER (LGBT) DIKAITKAN DENGAN DELIK KESUSILAAN DI DALAM KITAB UNDANG-UNDANG HUKUM PIDANA
}

\author{
Ateng Sudibyo \\ Fakultas Hukum Universitas Majalengka \\ Jl. K.H. Abdul Halim No. 103 Majalengka Kulon, Majalengka - Jawa Barat \\ Email: atengsudibyo080@gmail.com
}

\begin{abstract}
Abstrak
Kehadiran kelompok-kelompok LGBT di Indonesia sebenarnya telah menimbulkan kegemparan di masyarakat Indonesia, karena telah dianggap sebagai perlawanan terhadap agama, alam, dan nilai-nilai yang hidup dalam masyarakat Indonesia yang tidak pernah membiarkan tindakan seperti itu. Tindakan LGBT adalah tindakan yang melanggar aturan agama dan nilai kehidupan beragama di masyarakat Indonesia. Namun ironisnya tidak ada payung hukum khusus untuk mengatur masalah LGBT meskipun jika dilihat dari sifat ilegal suatu tindakan, bahkan jika tindakan tersebut tidak diatur dalam undang-undang dan peraturan (terhadap hukum formal), tetapi jika akta itu dianggap tercela karena keadilan atau normanorma kehidupan sosial dalam masyarakat (melawan hukum materi) maka tindakan tersebut dapat dihukum. Tujuan dari penelitian ini adalah untuk mengetahui kebijakan perundangundangan tentang LGBT dalam pelanggaran kesusilaan KUHP dan untuk merumuskan konsep kebijakan pidana LGBT dalam pelanggaran kesusilaan Hukum Masa Depan Hukum Pidana di Indonesia. Penelitian ini menggunakan pendekatan yuridis normatif dan sifat penelitian ini adalah deskriptif analitis. Pengambilan data dilakukan melalui studi pustaka untuk mendapatkan data sekunder, baik dalam bentuk bahan hukum primer, bahan hukum sekunder, dan bahan hukum tersier. Untuk mendukung penelitian yang telah dilakukan, penelitian lapangan juga dilakukan untuk mendapatkan data primer yang mendukung data sekunder. Analisis teknis yang digunakan dalam penelitian ini adalah teknik analisis kualitatif.
\end{abstract}

\section{Kata Kunci: Kebijakan Kriminal, LGBT, Hukum Pidana}

\section{Abstract}

The presence of LGBT groups in Indonesia has in fact caused a stir in Indonesian society, because it has been regarded as a resistance to religion, nature, and values that live in Indonesian society which has never allowed such acts. LGBT acts are acts that violate the rules of religion and the value of religious life in Indonesian society. But ironically there is no legal umbrella specifically to regulate the LGBT problem even though if it is viewed from the illegal nature of an act, even if the act is not regulated in laws and regulations (against formal law), but if the deed is considered despicable because justice or norms of social life in society (against material law) then the action can be punished. The purpose of this study is to find out the legislation policy on LGBT in the offense of decency of the Criminal Code and to formulate the concept of LGBT criminal policy in decency offenses of the Law Future Criminal Law in Indonesia. This study uses a normative juridical approach and the nature of this research is descriptive analytical. Data retrieval is done through library studies in order to obtain secondary data, both in the form of primary legal materials, secondary legal materials, and tertiary legal materials. To support the research that has been carried out, field research is also carried out in order to obtain primary data that supports secondary 
DE IEGA LATA

Jurnal Ilmu Hukum

FAKULTAS HUKUM UMSU
Kebijakan Kriminal Terhadap...(Ateng Sudibyo)

Volume 4 Nomor 1, Januari-Juni 2019, 28-41

DOI: https://doi.org/10.30596/dll.v4i1.3169

data. The technical analysis used in this study is a qualitative analysis technique.

Keywords: Policy, Criminal, LGBT, Law, Crime

\section{PENDAHULUAN}

Di Indonesia polemik tentang Lesbian,Gay, Biseksual dan Transgender yang selanjutnya disingkat LGBT berkembang dengan pro dan kontra. Kelompok yang berpendapat bahwa LGBT adalah sebuah 'fakta' sehingga harus diberi hak setara di dalam undang-undang sebagaimana telah dilakukan di berbagi negara, kontra dengan kelompok yang berpendapat bahwa perkawinan sesama jenis bukan "moral" sehinga tidak akan mendapat tempat di dalam hukum Indonesia.

Di Indonesia, LGBT ini sudah menyebar ke beberapa wilayah kota-kota besar, perilaku menyimpang ini sudah sangat meresahkan seluruh elemen masyarakat khususnya yang ada di Indonesia. Bagaimana tidak, LGBT ini sudah merusak peradaban manusia dan menyalahi aturan yang sudah ditentukan dalam kodrat manusia. Tidak hanya merubah kodrat manusia, LGBT ini juga nantinya akan berimbas pada kejahatan baru atau kriminalitas dimana kejahatan ini jika dibiarkan akan berakibat buruk pada masa depan bangsa Indonesia.( Wahyu Muljono, 2012, h. 3). Oleh karena itu perlu adanya kepastian hukum yang tegas untuk mengatur masalah tersebut.

Berbicara mengenai hukum, maka Thomas Aquinas sebagaimana dikutipoleh Achmad Ali menjelaskan definisi konsephukum. Ia menyebutkan bahwa hukum adalahsuatu aturan atau ukuran dari tindakan-tindakan,dalam hal mana manusia dirangsanguntuk bertindak (sesuai aturan atau ukuran itu), atau dikekang untuk tidak bertindak (sesuaidengan aturan atau ukuran itu). Sebagaimanadiketahui, perkataan lex (law, hukum) adalahberasal dari kata ligare (mengikat), sebab iamengikat seseorang untuk bertindak (menurutaturan atau ukuran tertentu). Hukum tidak lainmerupakan perintah rasional tentang sesuatu,yang memerintahkan hal-hal umum yangbaik, disebarluaskan melalui perintah yangdiperhatikan oleh masyarakat (Achmad Ali, 2009, h. 419).

Pengertian hukum yang dikemukakan oleh Thomas Aquinas ini memberikan pemahaman kepada kita ukuran dari tindakan baik bagi seseorang adalah ukuran rasional dari pembuat aturan. Dalam konteks pidana, ukuran rasional itu bisa kita lihat dari nilai pokok keberadaan hukum pidana. Misalnya seperti tujuan untuk menciptakan keamanan dan ketertiban dalam satu masyarakat. Sehingga pada titik tertentu bisa melahirkan keseimbangan di dalam masyarakat, karena dengan hukum pidana bisa diciptakan keadilan, kedamaian, dan kebahagian dalam satu masyarakat. Seperti yang disampaikan oleh Purnadi Purbacaraka dan Ridwan Halim, bahwa:

Eksistensi hukum pidana pada dasarnya meliputi nilai-nilai pokok: Keamanan dan ketertiban sebagai tujuan langsung hukum pidana, yang mutlak harus dapat dicapai; Kesadaran warga masyarakat akan makna dan hakikat umum yang kemudian dapat menjadi sumber keadilan, kedamaian, kesejahteraan rohaniah dan jasmaniah, sebagai tujuan akhir hukum pidana; Keserasian antara kejasmanian (aspek lahir) dan kerohanian 
DE LEGA LATA

Jurnal Ilmu Hukum

FAKULTAS HUKUM UMSU
Kebijakan Kriminal Terhadap...(Ateng Sudibyo)

Volume 4 Nomor 1, Januari-Juni 2019, 28-41

DOI: https://doi.org/10.30596/dll.v4i1.3169

(aspek batin) maupun kebaruan dan kelestarian harus dicapai dalam penerapan hukum pidana (Purnadi Purbacaraka dan A. Ridwan Halim, 1997, h. 1).

Kandungan nilai-nilai pokok itu tersebar dalam berbagai aspek. Mulai kandungan dalam rasio legis dibentuknya aturan hukum pidana hingga ukuran efektivitas dan efisiensi suatu aturan hukum pidana yang telah dirumuskan. Hakikat nilai pokok dasar pemikiran dirumuskannya aturan pidana antara lain: Untuk mengatur keserasian antar kepentingan pribadi dan kepentingan umum. Untuk sedapat mungkin mencapai dan mewujudkan aturan hukum yang telah dirumuskan dalam kehidupan masyarakat, di mana hukum itu berlaku melalui penerapan hukum pidana yang bersangkutan. Sebagai titik uji utama bagi masyarakat pada umumnya dan para ahli hukum atau pembentuk undang-undang pada khususnya untuk mengukur sejauh manakahefektivitas dan efisiensi itu ada pada suatu hukum pidana (Purnadi Purbacaraka dan A. Ridwan Halim, 1997, h. 2).

Salah satu kandungan nilai pokok dari keberadaan hukum pidana sebagai titikuji bagi masyarakat dan ahli hukum untuk mengukur efektivitas dan efisiensi satu aturan hukum pidana maka perlu diperhatikan unsur kebaruan dan kelestarian hukum pidana. ( Purnadi Purbacaraka dan A. Ridwan Halim, 1997, h. 3). Hal demikian untuk mengantisipasi apabila ada kekosongan hukum, kekaburan norma, maupun konflik norma dalam hukum pidana. Terlebih dalam perkembangan kehidupan masyarakat yang semakin dinamis (Barda Nawawi Arief, 2010, h. 15).

Tafsir kejahatan sering dikaitkan dengan perbuatan melawan hukum (melawan normahukum pidana). Dalam pandangan kriminolgi (positivistis) di Indonesia, kejahatandipandang sebagai pelaku yang telah diputus oleh Pengadilan; Perilaku yang perludekriminalisasi; Populasi pelaku yang yang ditahan; Perbuatan yang melanggar norma; Perbuatan yang mendapat reaksi sosial. Lebih lanjut beberapa ahli kriminologi menafsirkan kejahatan, antara lain; W.A. Bonger yangmenyebutkan kejahatan merupakan perbuatananti sosial yang secara sadar mendapatkanreaksi dari negara berupa pemberian deritadan kemudian, sebagai reaksi-reaksi terhadaprumusan hukum (legal definition) mengenaikejahatan. Selain itu juga ada Sutherlandyang mengartikan kejahatan sebagai perilakuyang dilarang oleh negara karena merugikan,terhadapnya negara bereaksi denganhukuman sebagai upaya mencegah danmemberantasnya (Yesmil Anwar dan Adang,2013, h. 178).

Definisi kejahatan yang merupakan produksosial, oleh para pakar dibedakan menjadi dua,yakni perbuatan mala probihita dan mala inse. Perbuatan yang didefinisikan sebagai malaprohibita menunjuk pada perbuatan yang tidak dengan sendirinya dipandang buruk, akan tetapi karena hukum mendefinisikannya sebagai pelanggaran atau kejahatan. Sementara mala in se adalah perbuatan yang buruk dengan sendirinya, perilaku terlarang yang didasarkan kesepakatan atau konsensus luas tentang tata atau norma kelakuakan bagi satu larangan (Frank E. Hagan, 2013: 9). Dengan demikian ada perbuatan yang dinilai oleh masyarakat dengan ukuran norma-norma sosial sebagai perbuatan jahat meskipun menurut norma hukum (khususnya hukum pidana) perbuatan itu bukan perbuatan jahat (Riswan Erfa, 2015, h. 239). 
DE LEGA LATA

Jurnal Ilmu Hukum

FAKULTAS HUKUM UMSU
Kebijakan Kriminal Terhadap...(Ateng Sudibyo)

Volume 4 Nomor 1, Januari-Juni 2019, 28-41

DOI: https://doi.org/10.30596/dll.v4i1.3169

Kehadiran kelompok LGBT di Indonesia pada kenyataannya telah menimbulkan kegaduhan di tengah masyarakat Indonesia, karena telah dianggap sebagai perlawanan terhadap agama, kodrat, dan nilai yang hidup dalam masyarakat Indonesia yang tidak pernah memperbolehkan perbuatan yang demikian. Perbuatan LGBT adalah perbuatan yang sangat melanggar aturan agama dan nilai kehidupan yang religius di dalam masyarakat Indonesia.

Mengenai komunitas LGBT yang sedang hangat dibicarakan di tanah air ini sebenarnya menuai banyak kekurangan didalam hal peraturan hukum yang mengaturnya, pengaturan hukum mengenai kejahatan terhadap kesopanan diatur didalam KUHP terdapat dalam buku II Bab XIV Pasal 281 hingga Pasal 303 KUHP. Dalam hal ini, perlu pula diketahui apa yang dimaksud dengan kesopanan dalam Pasal 281 KUHP. Menurut R. Soesilo menjelaskan bahwa yang dimaksud dengan kesopanan yaitu dalam arti kata kesusilaan, perasaan malu yang berhubungan nafsu kelamin misalnya bersetubuh, meraba buah dada perempuan, meraba tempat kemaluan wanita, memperlihatkan anggota kemaluan wanita atau pria, mencium, dan sebagainya. Pengerusakan kesopanan ini semuanya dilakukan dengan perbuatan. Sifat merusak kesusilaan perbuatan-perbuatan tersebut kadang-kadang amat tergantung pada pendapat umum pada waktu dan tempat itu.

Jika melihat Pasal 292 KUHP bahwa maksud dari pasal tersebutditujukan kepada korban sesama jenis yang usianya dibawah umur atau belum dewasa atau masih anak-anak, jelas ini sangat berbeda dan tidak dapat dijadikan dasar hukum jika kasus LGBT yang akan ditanganinya, artinya bahwa disini pun masih terdapat kekosongan hukum yang harus segera dibenahi jika negara benar-benar ingin melawan komunitas LGBT yang sudah sangat meresahkan, negara juga harus bisa mengobati para LGBT karena LGBT merupakan suatu penyakit yang pasti bisa disembuhkan.

Perkembangan multipologi kejahatan baru yang dianggap koruptif, tercela, dan merugikan masyarakat dalam skala yang sangat besar, seringkali kejahatan itu tidak terjangkau oleh peraturan perundang-undangan tertulis yang ada sanksi pidananya, dengan demikian, pelaku dapat bertindak secara bebas, dengan berlindung di balik asas legalitas, akan tetapi apabila ditinjau dari sifat melawan hukum nya suatu perbuatan maka meskipun perbuatan tersebut tidak diatur dalam peraturan perundang-undangan (melawan hukum formil), namun apabila perbuatan tersebut dianggap tercela karena tidak sesuai dengan rasa keadilan atau norma-norma kehidupan sosial dalam masyarakat (melawan hukum materil) maka perbuatan tersebut dapat dipidana.

Menentukan perbuatan itu dapat dipidana, pembentuk undang-undang menjadikan sifat melawan hukum sebagai unsur yang tertulis. Tanpa unsur ini, rumusan undang-undang akan menjadi terlampau luas. Sifat ini juga dapat dicela kadang-kadang dimasukkan dalam rumusan delik culpa.

Jika unsur melawan hukum itu dengan tegas terdapat di dalam rumusan delik, maka unsur juga harus dibuktikan, sedangkan jika dengan tegas dicantumkan maka tidak perlu dibuktikan. Untuk menentukan apakah suatu perbuatan dikatakan perbuatan melawan hukum diperlukan unsur-unsur: 1) Perbuatan tersebut melawan hukum; 2) Harus ada kesalahan pada 
DE IEGA LATA

Jurnal Ilmu Hukum

FAKULTAS HUKUM UMSU
Kebijakan Kriminal Terhadap...(Ateng Sudibyo)

Volume 4 Nomor 1, Januari-Juni 2019, 28-41 DOI: https://doi.org/10.30596/dll.v4i1.3169

pelaku; 3) Harus ada kerugian (Theodorus M. Tuanakotta, 2009, h. 73).

Berkembangnya atau meningkatnya LGBT jika dilihat dari hakikat kejahatan, itu merupakan masalah kemanusiaandan masalah sosial yang tidak dapat di atasi semata-mata dengan hukum pidana sebagai suatu masalah sosial, kejahatan merupakan suatu fenomena kemasyarakatan yang dinamis, yang selalu tumbuh dan terkait dengan fenomena dan struktur kemasyarakatan lainnya yang sangat kompleksdan berada di luar jangkauan hukum pidana (Muladi, 1995, h. 7). maka wajarlah hukum pidana mempunyai keterbatasan kemampuan untuk menanggulanginya, seperti halnya yang disampaikan Sudarto sebagaimana dikutip (Barda Nawawi Arief, 2005, h. 44), bahwa penggunaan hukum pidana merupakan penanggulangan suatu gejala 'kurrien am symptom' dan bukan suatu penyelesaian dengan menghilangkan sebab-sebabnya".

Jadi, keterbatasan kemampuan hukum pidana selama ini juga disebabkan oleh sifat/ hakikat dan fungsi hukum pidana itu sendiri. Sanksi (hukum) pidana selama ini bukanlah obat (remedium) untuk mengatasi sebab-sebab (sumber) penyakit, melainkan sekedar untuk mengatasi gejala/akibat dari penyakit sehingga harus ada upaya lain yang dilakukan untuk menanggulangi kejahatan. Adapun upaya lain selain hukum pidana yang berusaha menanggulangi kejahatan inilah kemudian dapat dikatakan sebagai upaya non penal, yaitu suatu upaya rasional dalam menanggulangi kejahatan dengan upaya-upaya lain selain hukum pidana (penal), namun jika dilihat dari kebijakan/ kriminal (kebijakan penanggulangan kejahatan) sebaiknya ditempuh dengan pedekatan/kebijakan integral, baik dengan menggunakan "penal" maupun dengan sarana "non-penal" ke arah penekanan atau pengurangan faktor-faktor potensial bagi tumbuh suburnya tindak pidana dan keduanya dalam fungsinya harus berjalan beriringan secara sinergis, saling melengkapi.

Langkah-langkah operasionalisasi politik kriminal dengan menggunakan sarana penal yang baik, dilakukan melalui: (Widiada Gunakaya dan Petrus Irianto, 2012, h. 10)

1. Penetapan kebijakan perundang-undangan (dapat juga disebut kebijakan legislasi/ formulatif) yang didalamnya berisikan penetapan kebijakan mengenai:

a. Perbuatan apa yang seharusnya dijadikan tindak pidana (kebijakan kriminalisasi);

b. Sanksi apa yang sebaiknya digunakan atau dikenakan kepada si pelanggar (kebijakan penalisasi/kebijakan pemidanaan).

2. Penerapan pidana oleh badan pengadilan (disebut juga kebijakan aplikasi/ yudikasi).

3. Pelaksanaan pidana oleh aparat pelaksana pidana (disebut juga kebijakan eksekusi)

Pelaksanaan penggunaan sarana hukum pidana (sarana penal), haruslah merupakan suatu usaha yang dibuat dengan sengaja dan sadar. Artinya, pilihan dan penetapan hukum pidana sebagai sarana untuk menanggulangi kejahatan harus benar-benar telah memperhitungkan semua faktor yang dapat mendukung berfungsinya atau bekerjanya hukum pidana itu dalam kenyataannya. Dengan demikian diperlukan pendekatan yang fungsional, dan inipun merupakan pendekatan yang melekat pada setiap kebijakan yang rasional (Barda Nawawi Arief, 1996, h. 39). Sedangkan kebijakan non penal (di luar hukum pidana), yang 
DE LEGA LATA

Jurnal Ilmu Hukum

FAKULTAS HUKUM UMSU
Kebijakan Kriminal Terhadap...(Ateng Sudibyo)

Volume 4 Nomor 1, Januari-Juni 2019, 28-41

DOI: https://doi.org/10.30596/dll.v4i1.3169

antara lain dilakukan dengan kebijakan ekonomi, budaya, sosial, agama, pendidikan, teknologi, dan lain-lain. Tujuan utama dari usaha-usaha non penal selain diharapkan mampu memperbaiki kondisi-kondisi sosial tertentu, secara tidak langsung mempunyai pengaruh preventif terhadap kejahatan (Muladi dan Barda Nawawi Arief, 2005, h. 159).

Berdasarkan uraian di atas, maka perlu dilakukan penanggulangan terhadap LGBT, yaitu dengan menggunakan kebijakan integral antara sarana penal dan non-penal (kebijakan kriminal) sehingga upaya penanggulangan kejahatan diharapkan dapat terlaksana secara sistematis. Demi tercapai kebijakan kriminal seperti yang diharapkan, penulis memandang perlu melaksanakan penelitian tentang "Kebijakan Kriminal Terhadap,GayBiseksual Dan Transgender (LGBT) dikaitkan dengan Delik Kesusilaan Di Dalam Kitab Undang-Undang Hukum Pidana".

\section{METODE PENELITIAN}

Jenis penelitian ini adalah yuridis normatif, karena kajian dalam penelitian ini adalah kajian ilmu hukum, oleh karena itu harus dikaji dari aspek hukumnya. Penelitian yuridis normatif disebut juga penelitian hukum kepustakaan (Ronny Hanitijo Soemitro, 1988, h. 11), atau dikategorikan sebagai penelitian yang mengkaji asas-asas dan kaidah-kaidah hukum (Ronny Hanitijo Soemitro, 1990, h. 11-12). Digunakannya penelitian hukum normatif, karena permasalahan pokoknya mengenai LGBT dikaitkan dengan delik kesusilaan, dan pendekatannya menggunakan pendekatan perundang-undangan (statute approach) yaitu dilakukan dengan menelaah semua undang-undang dan regulasi yang berkaitan dengan LGBT.

Penelitian ini bersifat deskriptif analitis, maksudnya karena peneliti berusaha mengetahui dan memaparkan informasi dan data secara faktual dengan cara sistematis dan akurat mengenai LGBT. Bersifat analitis karena peneliti akan melakukan analisis terhadap berbagai aspek hukum, baik dari segi peraturan, maupun dari segi pelaksanaannya, guna mengetahui upaya pencegahan terhadap LGBT.

Di dalam memperoleh data yang relevan dengan permasalahan yang diteliti, maka penelitian ini dilaksanakan dalam 2 (dua) tahap, yaitu: pertama, penelitian kepustakaan dan kedua, studi lapangan. Penelitian kepustakaan dilakukan dalam rangka memperoleh data sekunder, baik yang berupa bahan hukum primer, bahan hukum sekunder, maupun bahan hukum tertier (Soerjono Soekanto dan Sri Mamudji, 2003, h. 13). Bahan hukum primer adalah bahan hukum yang bersifat autoritatif (mempunyai otoritas), dan bahan-bahan hukum yang mengikat, yakni norma (dasar) atau kaidah dasar dan peraturan-peraturan dasar, seperti UUD 1945, serta peraturan perundang-undangan yang berkaitan dengan LGBT. Bahan hukum sekunder adalah bahan hukum yang memberikan penjelasan mengenai bahan hukum primer, berupa hasil-hasil penelitian, karangan ilmiah dari kalangan hukum, dan penelitian-penelitian lain yang relevan dengan penelitian ini, sedangkan bahan hukum tertier adalah bahan yang memberikan petunjuk ataupun penjelasan terhadap bahan hukum primer dan bahan hukum sekunder, berupa kamus, ensiklopedia, majalah, surat kabar dan sebagainya yang 
Jurnal Ilmu Hukum

FAKULTAS HUKUM UMSU
Kebijakan Kriminal Terhadap...(Ateng Sudibyo)

Volume 4 Nomor 1, Januari-Juni 2019, 28-41

DOI: https://doi.org/10.30596/dll.v4i1.3169

dipergunakan untuk melengkapi ataupun menunjang data penelitian ini. Selanjutnya studi lapangan dilakukan dalam rangka memperoleh data primer yang menunjang data sekunder, sehingga dari data primer akan diketahui pelaksanaan penanggulangan LGBT.

Teknik pengambilan data yang dilakukan adalah dengan menggunakan teknik:

1. Studi kepustakaan, yaitu dengan mempelajari literatur-literatur yang ber-hubungan dengan objek penelitian.

2. Wawancara (interview), yaitu mengumpulkan data melalui tanya jawab dengan para pihak yang terkait dengan objek penelitian, sedangkan tipe wawancara yang dipergunakan adalah wawancara tidak terpimpin (non directive interview), artinya seluruh wawancara tidak didasarkan pada satu sistem atau daftar pertanyaan yang telah disusun terlebih dahulu.

Setelah data sekunder dan primer terkumpul, kemudian diadakan analisis secara yuridis kualitatif, yaitu menganalisis data berupa uraian-uraian yang sistematis tanpa mempergunakan bagan-bagan dan rumus statistik.

\section{PEMBAHASAN}

\section{Kebijakan Legislasi Terhadap LGBT dalam Delik Kesusilaan Kitab Undang-Undang Hukum Pidana}

Tahap kebijakan legislasi merupakan suatu tahap yang akan menghasilkan suatu peraturan hukum yang akan menjadi pedoman pada tahap-tahap berikutnya dalam proses kebijakan hukum. Produk legislatif yang dinamakan undang-undang ini dalam tataran kebijakan hukum merupakan tataran formulasi atau legislasi, dan posisinya berada dalam tataran abstrak (berupa peraturan/undang-undang), artinya undang-undang ini akan mempunyai makna, apabila diberlakukan dalam realitas. Untuk itu, agar undang-undang ini dapat terealisasi dalam masyarakat, diperlukan badan-badan yang dapat melaksanakannya yang dalam ilmu hukum/ilmu politik dinamakan badan eksekutif. Sedangkan badan yang bertugas menerapkan atau mengefektifkan peraturan perundang-undangan dinamakan badan yudisial/badan yudikatif yang mandiri dan netral, serta bebas dari campur tangan badan lainnya (Barda Nawawi Arief, 1994, h. 94-95).

Selain itu, masalah kebijakan formulasi/legislatif juga berhubungan dengan masalah penitensier, yang merupakan bagian terpenting dari kebijakan pemidanaan (sentencing policy), yang menurut Herbert L. Parker merupakan salah satu masalah kontroversial dalam hukum pidana ( Helbert L. Parker, 1968, h. 13-15).

Undang-Undang Nomor 11 Tahun 2012 tentang Pembentukan Peraturan Perundangundangan dalam Pasal 2 menyebutkan bahwa Pancasila sebagai segala sumber hukum negara. Hukum negara yang dilegitimasi oleh undang-undang tersebut salah satunya adalah peraturan tertulis yang di dalamnya terdapat norma atau aturan hukum yang mengikat secara umum, yang mana norma itu dibentuk atau ditetapkan oleh suatu lembaga negara yang atau pejabat yang berwenangmelalui mekanisme yang telah ditetapkan oleh peraturan perundangundangan. Maka dari itu segala norma hukum yang dilegitimasi oleh ketentuan undangundang tersebut harus mendasarkan sumbernya pada Pancasila.

Pembentukan peraturan perundang-undangan termasuk dalam konteks Peraturan 
DE LEGA LATA

Jurnal Ilmu Hukum

FAKULTAS HUKUM UMSU
Kebijakan Kriminal Terhadap...(Ateng Sudibyo)

Volume 4 Nomor 1, Januari-Juni 2019, 28-41

DOI: https://doi.org/10.30596/dll.v4i1.3169

perundang-undangan yang memuat ketentuan pidana, bisa kita maknai sebagai pembentukan norma baru maupun perbaikan norma yang telah ada. Diperlukannya suatu aturan atau norma baru apabila kekosongan norma. Seperti yang telah dikemukakan di awal pada bagian latar belakang, permasalahan hukum dalam penelitian ini adalah adanya kekosongan norma. Permasalahan tersebut adalah tidak adanya norma hukum pidana yang mengatur secara tegas ancaman pidana bagi LGBT. Sementara kenyataan hukum, perbuatan yang demikian ada di masyarakat dan perbutaan itu mengganggu keseimbangan hukum.

Salah satu hal yang menarik di dalam Kitab Undang-undang Hukum Pidana Indonesia adalah peletakan masalah LGBT sebagai sebuah 'fakta' sehingga persetubuhan sesama jenis kelamin (homoseksual) yang dilakukan secara suka sama suka antara orang dewasa tidak dimasukkan menjadi delik kesusilaan. Di dalam Pasal 292 dinyatakan bahwa hubungan seksual homoseksual atau berjenis kelamin sejenis laki-laki dengan laki-laki (gay), dan wanita dengan wanita (lesbian) yang telah dewasa bukan merupakan sebuah tindak pidana. Bagi hukum pidana Indonesia hubungan percabulan seperti ini adalah sebuah fakta yang tidak perlu diatur. Pengaturan dan larangan hanya diatributkan untuk melindungi "anak di bawah umur", artinya hubungan homoseksual yang menjadi tindak pidana hanya akan terjadi jika perbuatan tersebut dilakukan oleh anak di bawah umur atau sesama anak di bawah umur tujuannya adalah agar si anak tersebut tidak terganggu kejiwaannya di masa depannya nanti. Lebih lanjut di dalam Pasal 292 Kitab Undang-undang Hukum Pidana (KUHP) mengatakan "orang dewasa yang melakukan perbuatan cabul dengan orang lain sesama jenis kelamin, yang sepatutnya harus diduganya belum dewasa, diancam dengan pidana penjara paling lama lima tahun", dan di dalam Undang-Undang Nomor 35 Tahun 2014 Tentang Perlindungan Anak hukuman ini kemudian diperberat bagi pelaku dewasa, sedangkan terhadap pelaku sesama anak dengan diversi (Timbo Mangaranap Sirait, 2017, h. 636).

Penempatan hubungan seks homoseksual walaupun dilakukan dengan tidak sah tetapi KUHP menempatkan sebagai sebuah 'fakta' sehingga para pelaku tidak dapat dipidana, berbanding terbalik dengan penempatannya dengan hubungan seks heteroseksual yang tidak sah dianggap sebagai pelanggaran 'moral' sehingga di dalam Pasal 293 hingga Pasal 298 dianggap merupakan sebuah pelanggaran terhadap tindak pidana kesusilaan "Kesusilaan dengan kata kesopanan, dan mengartikan bahwa kesopanan pada umumnya mengenai adat istiadat kebiasaan yang baik dalam hubungan antara berbagai anggota masyarakat. Sedangkan kesusilaanjuga mengenai adat kebiasaan yang baik itu, tetapi khusus setidaknya mengenai kelamin (seks) seseorang" (Wirjono Prodjodikoro, 2012 , h. 112).

Homoseksual menunjuk kepada suatu perbuatan bersama melanggar kesusilaan antara dua orang berkelamin sama, jadi antara laki-laki dengan laki-laki, atau antara perempuan dengan perempuan (Wirjono Prodjodikoro, 2012, h. 120). Sedangkan yang dimaksud dengan kesusilaan adalah dalam arti yang luas. Bukan hanya menyangkut soal kebirahian atau sex saja, akan tetapi meliputi semua kebiasaan hidup yang pantas dan berahlak dalam suatu kelompok masyarakat (tertentu) yang sesuai dengan sifat-sifat dari masyarakat yang bersangkutan. Norma kesusilaan tidak hanya terbatas bagi orang-orang yang memeluk suatu 
DE LEGA LATA

Jurnal Ilmu Hukum

FAKULTAS HUKUM UMSU
Kebijakan Kriminal Terhadap...(Ateng Sudibyo)

Volume 4 Nomor 1, Januari-Juni 2019, 28-41 DOI: https://doi.org/10.30596/dll.v4i1.3169

agama tertentu saja, melainkan juga bagi mereka yang tidak mengakui sesuatu agama. Orang terdorong untuk mentaati norma-norma kesusilaan, karena keinginannya untuk hidup bermasyarakat tanpa semata-mata karena paksaan rohaniah atau jasmaniah (Y. Kanter dan S.R. Sianturi, 2002, h. 27).

Oleh itu perbuatan LGBT merupakan suatu perbuatan yang melanggar norma kesopanan dan patut diancam dengan pidana terutama yang berkaitan dengan delik kesusilaan. Meskipun Pasal 292 KUHP tidak dapat dijadikan dasar hukum karena tidak memenuhi unsur yang terkandung didalam pasal tersebut dan korbanya pun dibawah umur, namun apabila diamati dalam UU Nomor 44 Tahun 2008 Tentang Pornografi Pasal 4 ayat (1) huruf a yang menyatakan persenggamaan, termasuk persenggamaan yang menyimpang. Yang dimaksud dengan "persenggamaan yang menyimpang" antara lain persenggamaan atau aktivitas seksual lainnya dengan mayat, binatang, oral seks, anal seks, lesbian, danhomoseksual.

Jadi meskipun Pasal 292 KUHP tidak bisa dijadikan dasar untuk menjerat pelaku LBGT akan tetapi dalam Pasal 4 ayat 1 huruf a Undang-Undang Nomor 44 Tahun 2008 bisa dijadikan rujukan untuk menjerat pelaku LGBT, yang sanksi pidananya terdapat dalam Pasal 29 UU Nomor 44 Tahun 2008 dengan pidana penjara paling singkat 6 (enam) bulan dan paling lama 12 (dua belas) tahun dan/atau pidana denda paling sedikit Rp. 250.000.000,00 (dua ratus lima puluh juta rupiah) dan paling banyak Rp. 6.000.000.000,00 (enam miliar rupiah).

Berkaitan dengan paparan di atas, perlu pula diketahui apa yang dimaksud dengan kesopanan dalam Pasal 281 KUHP. Menurut R. Soesilo menjelaskan pula bahwa yang dimaksud dengan kesopanan yaitu dalam arti kata kesusilaan, perasaan malu yang berhubungan nafsu kelamin misalnya bersetubuh, meraba buah dada perempuan, meraba tempat kemaluan wanita, memperlihatkan anggota kemaluan wanita atau pria, mencium, dan sebagainya. Pengerusakan kesopanan ini semuanya dilakukan dengan perbuatan. Sifat merusak kesusilaan perbuatan-perbuatan tersebut kadang-kadang amat tergantung pada pendapat umum pada waktu dan tempat itu . LGBT merupakan suatu perbuatan yang bertentangan pendapat umum terutama pemuka adat dan agama yang ada di Indonesia, menolak perbuatan LGBT, oleh karena itu sudah sepantasnya perbuatan LGBT dijerat atau diancam dengan Pasal 281 KUHP.

\section{Konsep Kebijakan Kriminal LGBT dalam Delik Kesusilaan Kitab Undang-Undang Hukum Pidana Di Indonesia Masa yang Akan Datang}

Kebijakan kriminalisasi merupakan menetapkan perbuatan yang semula bukan tindak pidana menjadi suatu tindak pidana dalam aturan perundang-undangan. Pada hakikatnya kebijakan kriminalisasi merupakan bagian dari kebijakan kriminal dengan menggunakan sarana hukum pidana, dan oleh karena itu termasuk bagian dari kebijakan hukum pidana (Teguh prasetyo, 2010, h. 133). Dalam rangka menanggulangi kejahatan diperlukakan berbagai sarana sebagai reaksi yang dapat diberikan kepada pelaku kejahatan berupa pidana. Karena, pidana masih dianggap relevan untuk menanggulangi kejahatan, meski masih banyak 
DE LEGA LATA

Jurnal Ilmu Hukum

FAKULTAS HUKUM UMSU
Kebijakan Kriminal Terhadap...(Ateng Sudibyo)

Volume 4 Nomor 1, Januari-Juni 2019, 28-41

DOI: https://doi.org/10.30596/dll.v4i1.3169

reaksi lain yang berupa non-pidana dalam menanggulangi kejahatan.

Pidana sebagai sarana pengendalian kejahatan diperlukan adanya konsepsi politik dalam hukum pidana yakni mengadakan pemilihan untuk mencapai hasil perundang-undangan pidana yang sesuai dengan keadaan dan situasi pada suatu waktu dan untuk masa-masa yang akan datang. Konsepsi politik hukum pidana untuk menanggulangi kejahatan, disamping melalui pembuatan produk hukum berupa pembuatan undang-undang,hukum pidana tidak lepas juga dengan usaha menuju kesejahteraan masyarakat melalui kebijakan sosial (social policy). Hal ini berarti kebijakan untuk menanggulangi kejahatan dengan menggunakan sanksi pidana, harus pula dipadukan dengan usaha-usaha lain yang bersifat non-penal.

Dua masalah sentral dalam kebijakan kriminal dengan menggunakan sarana penal (hukum pidana) ialah masalah penentuan:

a. Perbuatan apa yang seharusnya dijadikan tindak pidana

b. Sanksi apa yang sebaiknya digunakan atau dikenakan kepada si pelanggar (Badra Nawawi Arief, 2010, h. 30).

Penganalisisan terhadap dua masalah sentral ini tidak dapat dilepaskan dari konsepsi integral antara kebijakan kriminal dengan kebijakan social atau kebijakan pembangunan hukum. Ini berarti pemecahan masalah-masalah di atas harus pula diarahkan untuk mencapai tujuan-tujuan tertentu dari kebijakan social politik yang telah ditetapkan. Dengan demikian, kebijakan hukum pidana, termasuk pula kebijakan dalam menangani dua masalah sentral di atas, harus pula dilakukan dengan pendekatan yang berorentasi pada kebijakan (policy oriented approach). Akan tetapi jika hukum diidentikkan dengan perundang-undangan, maka salah satu akibatnya dapat dirasakan, adalah kalau ada bidang kehidupan yang belum diatur dalam perundang-undangan, maka dikatakan hukum tertinggal oleh perkembangan masyarakat. Demikian juga kepastian hukum tidak identik dengan dengan kepastian undangundang. Apabila kepastian hukum diidentikkan dengan kepastian undang-undang, maka dalam proses penegakan hukum dilakukan tanpa memperhatikan kenyataan hukum yang berlaku.

Sudarto berpendapat bahwa dalam menghadapi masalah sentral di atas yang sering disebut sebagai masalah kriminalisasi, harus memperhatikan hal-hal yang pada intinya sebagai berikut: (Badra Nawawi Arief, 2010, h. 36)

a. Penggunaan hukum pidana harus memperhatikan tujuan pembangunan nasional, yaitu mewujudkan masyarakat adil dan makmur yang merata materiil dan spiritual berdasarkan pancasila. Sehubungan dengan ini maka penggunaan hukum pidana untuk menanggulangi kejahatan demi kesejahteraan dan pengayoman masyarakat.

b. Perbuatan yang diusahakan untuk dicegah atau ditanggulangi dengan hukum pidana harus merupakan 'perbuatan yang tidak di kehendaki' yaitu perbuatan yang mendatangkan kerugian materiil ataupun spiritual atau warga masyarakat.

c. Penggunaan hukum pidana harus pula memperthitungkan prinsip 'biaya dan hasil' (cost benefit principle). 
Jurnal Ilmu Hukum

FAKULTAS HUKUM UMSU
Kebijakan Kriminal Terhadap...(Ateng Sudibyo)

Volume 4 Nomor 1, Januari-Juni 2019, 28-41 DOI: https://doi.org/10.30596/dll.v4i1.3169

d. Penggunaan hukum pidana harus pula memperhatikan kapasitas atau kemampuan daya kerja dari badan-badan penegak hukum, yaitu jangan sampai ada kelampauan beban tugas (overbelasting).

Perbuatan LGBT juga seringdianggap sebagai penyakit yangmenular, untuk itu selain merumuskandengan baik perbuatan itu sebagaitindak pidana dengan kebijakan hukum pidananya, namun juga harus disertai dengan tujuan pemidanaan yang dapat menanggulangi perbuatan tersebut yang juga berorientasi pada perbaikan dan pengobatan terhadap pelaku. Tidak hanya mengedepankan suatu tindakan pembalasan yang menjadi tujuan dari teori pemidanaan retributif. Kebijakan hukum pidana pada dasarnya mempelajari masalah bagaimana sebaiknya hukum pidana itu dibuat, disusun dan digunakan untuk mengatur/mengendalikan tingkah laku manusia, khususnya untuk menanggulangi kejahatan dalam rangka melindungi dan mensejahterakan masyarakat.(Barda Nawawi Arief, 2016:8). Dengan demikian, maka tujuan pemidanaan adalah untuk memperbaikikerusakan baik yang bersifat individual, maupun yang bersifat sosial (individualand social damages) yang diakibatkan oleh tindak pidana. Tujuan pemidanaan harus berorientasi pada pandangan yang integratif, yang terdiri dari seperangkat tujuan pemidanaan yang harus dipenuhi, dengan catatan bahwa, tujuan manakah yang merupakan titikberat sifatnya kasuistis (Barda Nawawi Arief, 2016, h. 11). Seperti kasus LGBT, tujuan pemidanaan diarahkan kepada perbuatan si pelaku juga demi perbaikan diri pelaku LGBT sendiri.

Seperti yang dilakukan dengan rancangan KUHP yang akan datang, tim perancang konsep KUHP Nasional telah sepakat bahwa tujuan pemidanaan adalah: (Barda Nawawi Arief, 2016, h. 11)

a. Mencegah dilakukannya tindak pidana dalam menegakkan norma hukum demi pengayoman masyarakat;

b. Memasyarakatkan terpidana dengan mengadakan pembinaan sehingga menjadikannya orang yang baik dan berguna;

c. Menyelesaikan konflik yangditimbulkan oleh tindak pidana,memulihkan keseimbangan dnamendatangkan rasa damai dalammasyarakat;

d. Membebaskan rasa bersalah pada terpidana.

Disinilah harusnya arah politik hukum pidana atau kebijakan hukum pidana dalam menanggulangi perbuatan LGBT, dengan menitik beratkan pada tujuan pemidanaan yang dapat memberikan perbaikan dan pembinaan serta dapat membuat efek jera pada pelaku perbuatan LGBT, serta mengembalikan keseimbangan, keselarasan dan keserasian dalam masyarakat, dan menjaga kesucian nilai-nilai keseimbangan yang ada pada Pancasila terutama nilai ke-Tuhanan. Kebijakan criminal dalam menanggulangi perbuatan LGBT diarahkan juga untuk membina pelaku agar kembali dapat diterima dalam masyarakat yang beradab dan mendapatkan kesembuhan selain mendapatkan pemidanaan. Karena perbuataan ini dianggap sebagai penyakit yang dapat menular melalui pergaulan. 
Jurnal Ilmu Hukum

FAKULTAS HUKUM UMSU
Kebijakan Kriminal Terhadap...(Ateng Sudibyo)

Volume 4 Nomor 1, Januari-Juni 2019, 28-41 DOI: https://doi.org/10.30596/dll.v4i1.3169

\section{KESIMPULAN DAN SARAN \\ Kesimpulan}

Kebijakan legislasi terhadap LGBT apabila mengacu pada Pasal 292 KUHP tidak bisa dijadikan dasar untuk menjerat pelaku LBGT akan tetapiapabila kita lihat Pasal 4 ayat (1) huruf a UU Nomor 44 Tahun 2008 Tentang Pornografi bisa dijadikan rujukan untuk menjerat pelaku LGBT, yang sanksi pidananya terdapat dalam Pasal 29 Undang-Undang Nomor 44 Tahun 2008 Tentang Pornografi dan LGBT merupakan suatu perbuatan yang bertentangan pendapat umum terutama pemuka adat dan pemuka agama di Indonesia yang menolak perbuatan LGBT, oleh karena itu sudah sepantasnya perbuatan LGBT dijerat atau diancam pula dengan Pasal 281 KUHP. Konsep kebijakan kriminal terhadap LGBT tidak hanya dapat dilakukan dengan pendekatan penal, karena faktor yang menyebabkan kejahatan sangat komplek, yang berada di luar jangkauan hukum pidana, sedangkan hukum pidana mempunyai keterbatasan kemampuan untuk menanggulanginya. Mengingat adanya keterbatasan kemampuan hukum pidana, maka untuk mengatasi LGBT perlu ditempuh dengan kebijakan kriminal (criminal policy) yang menggunakan pendekatan penal dan non-penal.

\section{Saran}

Pemerintah perlu membuat payung hukum yang khusus mengatur LGBT dengan memasukan sanksi pidana yang berupa pidana penjara dan selama belum ada payung hukum yang khusus mengenai larangan LGBT, pemerintah secepatnya melakukan kampanyekampanye anti LGBT, untuk menghindari lose generation di masa dating. Penanggulangan LGBT, sebaiknya lebih difokuskan pada upaya pencegahannya dengan cara menghilangkan faktor-faktor signifikan yang dapat menimbulkan atau membuka peluang bagi terjadi tindak pidana tersebut. 
Jurnal Ilmu Hukum

FAKULTAS HUKUM UMSU
Kebijakan Kriminal Terhadap...(Ateng Sudibyo)

Volume 4 Nomor 1, Januari-Juni 2019, 28-41 DOI: https://doi.org/10.30596/dll.v4i1.3169

\section{DAFTAR PUSTAKA}

Ali, Achmad. (2009). Menguak Teori Hukum (Legal Theory) dan Teori Peradilan (Judicialprudence). Jakarta: Kencana Prenada Media Grup.

Anwar, Yesmil., \& Adang. (2013). Kriminologi. Bandung: Refika Aditama.

Arief, Badra Nawawi. (2010). Bunga Rampai Kebijakan Hukum Pidana. Kencana Prenada Media Group.

Arief, Badra Nawawi. (1996). Kebijakan Legislatif dalam Penanggulangan Kejahatan dengan Pidana Penjara. Semarang: Badan Penerbit Universitas Dipoegoro.

Arief, Badra Nawawi. (2005). Beberapa Aspek Kebijakan Penegakan dan Pengembangan Hukum Pidana. Edisi Revisi. Bandung: Citra Aditya Bakti.

Arief, Badra Nawawi. (2015). Pembangunan Sistem Hukum Nasional (Indonesia). Semarang: Penerbit Pustaka Magister.

Arief, Badra Nawawi. (2016). Kebijakan Formulasi Ketentuan Pidana Dalam Peraturan Perundang-Undangan. Semarang: Pustaka Magister.

Arief, Badra Nawawi. (2016). Kumpulan Hasil Seminar Hukum Nasional Ke I s/d IX dan Konvensi Hukum Nasional 2008 Tentang Undang-Undang Dasar 1945 Sebagai Landasan Konstitusionazl Grand Design Sistem dan Politik Hukum Nasional. Semarang: Badan Penerbit Universitas Diponegoro.

Cahyadi, Antoniu., \& E. Fernando M. Manullang. (2007). Pengantar ke Filsafat Hukum. Jakarta: Kencana Prenada Media Group.

Darmodiharjo, Darji., \& Shidarta. (2008). Pokok-pokok Filsafat Hukum: Apa dan Bagaimana Filsafat Hukum Indonesia, Cetakan Ketujuh. Jakarta: Gramedia Pustaka Utama.

Gunakaya, Widiada., \& Irianto, Petrus. (2012). Kebijakan Kriminal Penanggulangan Tindak Pidana Pendidikan. Bandung: Alfabeta.

Hagan, Frank E. (2013). Pengantar Kriminologi (Teori, Metode dan Prilaku Kriminal Edisi Ketujuh). Jakarta: Kencana.

Jaya, Nyoman Sertikat Putra. (2017). Pembaharuan Hukum Pidana. Semarang: Pustaka Rizki Putra.

Kanter, E.Y., \& Sianturi, S.R.. (2002). Asas-asas Hukum Pidana di Indonesia dan Penerapannya. Jakarta: Storia Grafika.

Muladi., \& Arief, Barda Nawawi. (2005). Teori-Teori Dan Kebijakan Pidana. Bandung: Alumni.

Muladi. 1995. Kapita Selekta Sistim Peradilan Pidana. Semarang: Badan Penerbit UNDIP.

Muljono, Wahyu. (2012). Pengantar Teori Kriminologi. Yogyakarta: Penerbit Pustaka Yustisia.

Parker, Helbert L. (1968). The Limits of The Criminal Sanction. Calofornia: Stanford University Press.

Prasetyo, Teguh. (2016). Sistem Hukum Pancasila (Sistem, Sistem Hukum dan Pembentukan Peraturan Perundang-undangan di Indonesia, Perspektif Teori Keadilan Bermartabad. Bandung: Nusa Media.

Prasetyo, Teguh. (2010). Kriminalisasi Dalam Hukum Pidana. Bandung: Penerbit Nusa 
Jurnal Ilmu Hukum

FAKULTAS HUKUM UMSU
Kebijakan Kriminal Terhadap...(Ateng Sudibyo) Volume 4 Nomor 1, Januari-Juni 2019, 28-41 DOI: https://doi.org/10.30596/dll.v4i1.3169

Media.

Prodjodikoro, Wirjono. (2012). Tindak-tindak Pidana Tertentu Di Indonesia. Bandung: Refika Aditama.

Purbacaraka, Purnadi., \& Halim, A. Ridwan. (1997). Filsafat Hukum Pidana Dalam Tanya Jawab. Jakarta: Rajawali Press.

Soekanto, Soerjono., \& Mamudji, Sri. (2003). Penelitian Hukum Normatif Suatu Tinjauan Singkat. Jakarta: RajaGrafindo Persada.

Soemitro, Ronny Hanitijo. (1990). Metodologi Penelitian Hukum dan Jurimetri. Jakarta: Ghalia Indonesia.

Tuanakotta, Theodorus M. (2009). Menghitung Kerugian Keuangan Negara Dalam Tindak Pidana Korupsi. Jakarta: Salemba Empat.

Arief, Barda Nawawi. (1994). Kebijakan Legislatif Dalam Penanggulangan Kejahatan Dengan Pidana Penjara. (Disertasi. Semarang: UNDIP).

Muladi. (1990). Proyeksi Hukum Pidana Materil Indonesia Di Masa Datang. (Pidato Pengukuhan Guru Besar Ilmu Hukum Pidana

Arzaqi, Nila. (2018). Kebijakan Hukum Pidana Dalam Upaya Menanggulangi Lgbt (Lesbian, Gay, Biseksual, Dan Transgender) Berbasis Nilai-Nilai Pancasila. Jurnal. Refleksi Hukum Jurnal Ilmu Hukum, p-ISSN 2541-4984 | e-ISSN 2541-5417 Volume 2. Nomor 2. April.

Erfa, Riswan. 2015. Kriminalisasi Perbuatan Cabul Yang Dilakukan Oleh Pasangan Sesama Jenis Kelamin (Homoseksual). Jurnal Arena HukumVolume 8. Nomor 2. Agustus.

Winurini, Sulis. (2016). Memaknai Perilaku LGBT Di Indonesia (Tinjauan Psikologi Abnormal). Jurnal Info Singkat Kesejahteraan Sosial Vol. VIII, No. 05/I/P3DI/Maret.

Sirait, Timbo Mangaranap. (2017). Menilik Akseptabilitas Perkawinan Sesama Jenis di dalam Konstitusi Indonesia. Jurnal Konstitusi. Volume 14. Nomor 3. September. 